\title{
Rock Wallabies and Mayan Temples: The Landscapes of the Pilbara in Japanese Story and the Burrup Peninsula
}

\section{Delys Bird, University of Western Australia, Perth}

There is a long and well documented history of the ambiguous relationship that existed between Australian settler society and the Australian landscape. From the Renaissance on speculation about the existence of a great south land had given rise to ideas of an upside-down place of great riches and extraordinary fertility, so that the antipodes had been written into a European imagination long before settlement. Its reality - trees resistant to European axes, land resistant to European cultivation, an interior apparently devoid of water and vegetation; in essence a land that did not yield to Enlightenment ideologies of possession, improvement and cultivation was shocking to the settlers. Here was a land where culture could not easily overcome nature, and the formulation of this realisation exists in colonial letters, diaries and jottings, in explorers' journals as well as in fictional writings. Marcus Clarke wrote famously of the "weird melancholy"5 of the bush landscape, fascinating but threatening; later Henry Lawson described the landscape of "The Drover's Wife" with an equally famous series of negatives: "Bush all round-bush with no horizons ...". ${ }^{6}$ It is recorded too in the ways explorers named the landscape - Lake Disappointment, Mount Terrible, and ironically, Hopetown and so on.

Such inscriptions of the landscape indicate the ways an Australian national identity has been fixed to the British settlement of the land. Numerous commentators on aspects of Australian culture have pointed to the anxiety and ambivalence which seem endemic to Australian nationhood. These characteristics arguably have their origin in that experience of settlement in which the landscape, bush then desert, became what Roslyn Haynes refers to as a "psychological topography". Ross Gibson used the metaphor of a "diminishing paradise" in his book of the same 
name for the expectations which settlers brought with them and which receded in the face of the realities of settlement. He writes in a later book, South of the West, that the landscape would "define the nation". It came to be viewed as "an awesome opponent rather than a nurturing mother", sublime but intractable. ${ }^{8}$ These views of the land assumed it was unoccupied, a view now referred to as terra nullius, and one which was finally overturned by the legal recognition of native title to areas of the land, first in the momentous decision of the High Court Mabo vs Queensland (1990), ${ }^{9}$ then through the enactment of the Commonwealth Native Title Act (1993).

When gold was discovered, initially in Victoria in the 1850s, the land seemed to offer an alternative source of material wealth which could redeem the difficulties of realising the 'pastoral dream' of the settler society. And successive gold rushes, as well as mining in all its aspects became a major subject of Australian writing. The first novel of Henry Handel Richardson's Richard Mahony trilogy, Australia Felix, opens with a long poem which describes the Ballarat goldfields, scene of the first gold rushes. Here, enormous fortunes were made, money which built the city of Melbourne, soon considered one of the most modern in the world and tagged 'marvellous Melbourne'. The novel though seeks out the underside of the fields, in the suffering of the thousands of diggers whose only experience was extreme hardship, disappointment, disease and often death. Most significantly for my paper, it ends with a stark description of the despolation of the landscape, which nevertheless remains more powerful than its plunderers:

Such were the fates of those who succumbed to the 'unholy hunger'. It was like a form of revenge taken on them, for their loveless schemes of robbing and fleeing, a revenge contrived by the ancient, barbaric country they had so lightly invaded. Now, she held them captive - without chains; ensorcelled without witchcraft; and, lying stretched like some primeval monster in the sun, her breasts freely bared, she watched, with a malignant eye, the efforts made by these puny mortals to tear their lips away. ${ }^{10}$

All this provides a brief background to my interest in the ways these national myths, arising out of the settlement experience of the land, participate in the contemporary politics of large-scale mining of iron ore, oil and gas in the Pilbara region of North-West Western Australia. I'll take it up through a reading of the film Japanese Story, set partly in the Pilbara, and an aspect of the mining history of the Burrup Peninsula, also in the Pilbara.

The Pilbara is a desert landscape, and the desert, the true Australian outback, has been widely and memorably recorded by explorers and anthropologists, artists and 
writers and filmmakers as well as in tourist brochures. In her important study, Seeking the Centre, Roslynn Haynes investigates the significance of the desert in Australian culture, where it has been seen as a wilderness to be mapped, redeemed or exploited, a recalcritrant Nature defeating human endeavour or a timeless, numinous landscape inciting awe and fear. She reminds us that while Europeans "saw in the Australian desert only an enormous absence", for Aboriginal peoples, "the whole land is semiotic, a complex web of signs, pointing beyond themselves to a spiritual meaning". ${ }^{11}$ The land has been alive to Indigenous groups for more than 40,000 years and underpins Indigenous cultural life. This difference of view, one rational and scientific - the desert has to be made to yield - the other metaphysical - based in the idea of continual reciprocity between the land and its occupants - becomes part of the story of the contestation of land use in the Burrup Peninsula, one which is only implied in Japanese Story. It has been described from the Aboriginal perspective in this way: "If we lose this land we lose our culture. ... What's under the earth, whether there's gold or riches, we don't want the riches. We want the land." 12

According to Ross Gibson, "the majority of Australian feature [films] have been about landscape", ${ }^{13}$ and Japanese Story has been linked to what he calls the "landscape tradition" of Australian cinema. That tradition was especially strong in the 1970s when it established Australian film as an international genre. And it took a particular shape and form. Felicity Collins argues that "the longevity of the nonurban, outback landscape in Australian cinema over several decades has perpetuated the idea that somehow the national character, forged in the bush, will always be defeated by the desert." ${ }^{\text {"14 }}$ For Australian landscape cinema of the 1990s and later, however, that defeat is often presented as what Collins, writing of Japanese Story, calls "a barely-felt spiritual malaise" which "imbues its characters and landscapes". ${ }^{15}$ Central to Graeme Turner's 1986 study of Australian narrative in literature and film was the idea that Australian narrative depends on "Romantic opposition between Society and Nature", which "is resolved in favour of the search for some harmony with Nature". Turner argues that while the inhospitable nature of the land renders that search "fruitless", there are "compensations in the assertion of a unique natural beauty, in the discovery of a certain spirituality in communion with the land or in the mastery of the stoical, pioneering virtues of endurance and acceptance". ${ }^{16}$ By the last decade of the twentieth century, however, it was no longer possible to represent the land in such simple terms, and the idea that European settlement of Australia was a kind of land grab, together with the recognition that the land had been mistreated by those settlers, has given rise to a further recognition that a cultural mourning and reparation is now needed and that it must be undertaken in relation to the land and its original inhabitants. 
Many of these ideas are apparent in the ways Japanese Story presents the landscape of the Pilbara and the central characters whose lives are changed by their experience there. It opens with a birds' eye view of a gorgeously coloured, patterned landscape, then drops to a shot of a long, new bitumen road cutting through the desert. ${ }^{17}$ A single vehicle is on the road, driven by a Japanese visitor, a young businessman, Tachibama Hiromitsu. As he drives through this vast, remote space, he stops to photograph it and himself in it, to a background of Australian music as the Indigenous band Yothu Yindi's 'Treaty' plays. Disconcerted by his surroundings, Hiromitsu changes this to a CD of popular Japanese music. Several issues are established here: the foreignness of the visitor (who is dressed in dark suit and tie); the scale, stark beauty and apparent emptiness of the landscape through which he drives and in which he is represented as insignificant, and his discomfort with it all. Later, Sandy, a female geologist, flies from Perth to Port Hedland to join Hiromitsu and show him around the area. As they visit an iron ore plant in which his father's company has a joint interest (actually the BHP Billiton mine in the Pilbara) the film moves into documentary mode, inviting us to marvel as he does at its scale, as colossal machines scoop and crush the earth. Hiromitsu is excited by this display; even more so by the next mine they visit, five hours' driving away at Newman, where the modern technologies of mining have formed a fantastic landscape which he likens to a "Mayan temple"; the mine becomes today's equivalent of an ancient place of worship.

These scenes, with the group watching the workings of the mine, dwarfed by their gigantic scale, are a reminder of the global economy which resource ventures in this region of Western Australia are part of. They celebrate a new kind of nation building, dependent for its success on huge overseas investment. There are indications here though that this is a kind of plunder, and while the film itself does not invite the questions which arise from this scene, they nevertheless exist. Is it a good thing that the land is being used in this way, to this extent? Who is benefiting from this? What are the implications of major overseas investment in Australian industry? Further, can this fragile environment, already shown as so beautiful, sustain such an assault? These are questions which arise in an examination of the current controversy over resource development in the Burrup Peninsula.

The film returns to the desert landscape of the Pilbara as Sandy takes Hiromitsu, at his request, out into it. Now its mode is part travelogue, part road movie. There are indications that this journey will shift their relationship to each other and to the land, and the viewer can enjoy the landscape, as Sandy and Hiromitsu do, from the safety of the 4WD vehicle and the well marked road. One of the structures of the film, around nature and culture, a classic opposition basic to a range of Australian narrative forms according to Turner, has now been established. Culture has 
overtaken nature at the mine, nature is powerful in the desert, but Sandy knows her way and can tell its story to the visitor, so that culture is triumphant. At a stopping point though, Hiromitsu responds to it: "In Australia you have a lot of space", he says, "There is nothing. It scares me". He is right to be scared, and when he demands that Sandy leave the road and head out on a dirt track Sandy refuses; "People die out in this country, often, lots of people, all the time" she warns him and they are not prepared for any mishap. Hiromitsu insists, they become bogged, she cannot free the vehicle, and they are forced to spend the night in the freezing desert. They cannot make mobile contact, have little water and things look bad. However, the foreigner works to dig the vehicle out and they escape, bonded by this experience.

In the series of scenes I've described Hiromitsu represents the global corporate world; Sandy a national type, lean and laconic, tough and ironic, a female version of the familiar masculine outback character of numerous novels and films. She is wary and slightly contemptuous of the foreign visitor and cautious of entering the desert environment. All this invites speculation about the ways this film takes up and shifts aspects of the landscape tradition in Australian narrative and the questions it doesn't ask, or the story it doesn't tell. There lie its buried politics, which are recognised in one scene where Sandy and Hiromitsu, who have become lovers and are still travelling in the desert country, sit, dwarfed by a jagged pile of huge red rocks, gazing at a rock painting of a wallaby. Their voices are hushed as she asks him: "No photos?" to which he replies "No photos". This rather awkward scene appears to signify respect for the Indigenous culture whose land this is; yet recognition of that culture is notably absent from the rest of the film. Nevertheless, it has become a central issue among debates over the land and its use on the Burrup Peninsula area of the Pilbara.

Industrial development in the Pilbara region, including the Burrup Peninsula and the waters of the Dampier Archipelago has been supported by State and Federal Governments for the past thirty-five years. The site was chosen because it offered deep water and safe harbour facilities at Dampier, ones that are rare on the Western Australian coastline. Resource development commenced in the early 1960s, with iron ore plants, then solar salt fields. Natural gas was discovered in offshore waters in 1971, leading to establishment of the North West Shelf Project, which now exports Liquefied Natural Gas from Dampier. Increasing global demands for iron and gas as well as other minerals over the last decade and a half has resulted in an escalation of the demand on behalf of mining and resource companies for land. In 2000 the WA State Government launched an intention to acquire more land on the Burrup Peninsula and an adjacent area for the construction of a heavy industry estate. ${ }^{18}$ This history is a brief one in contrast to 
the Indigenous story of the Burrup, which has existed for many thousands of years as a sacred site for Aboriginal peoples of the area. It is marked by a remarkable collection of standing stone structures and rock engravings as well as midden, shell and grinding sites. A member of the Ngarluma Yindjibarndi group, one of the claimants to the Burrup, refers to the site as "the biggest monument to the whole of this land". ${ }^{19}$ There is as yet no systematic scientific survey of the huge site, due in part to the difficulties of much of the terrain and to the lag in recognition of the heritage significance of the area, although of course it is known to its traditional owners.

A 2006 Submission by the Western Australian Government to the Australian Heritage Council, written in response to that Council's recommendation that the Dampier Archipelago/Burrrup Peninsula be nominated to the National Heritage List defines the potential conflict among these interests as a simple one. It contends that the economic imperative of further development is crucial to the area, and that Heritage listing of the area would have "potentially grave consequences" for the economies of the State and the nation, as well as denying the local Indigenous population the "opportunities afforded by new development in the region". ${ }^{20}$ This document claims that adequate safeguards are in place to protect the Indigenous heritage values of the site, and that "existing State management and regulatory processes", together with "new fully funded heritage management initiatives endorsed by the State" will enable the area to "achieve world's best practice environment and heritage protection without the need for, or the complications arising from a single issue focussed National Heritage List approach". ${ }^{21}$

This position is at odds with that of many others involved in the debate around what the document recognises are the "conflicting land uses on the Burrup Peninsula", and avoids many of the issues that are part of that debate. My interest is not so much in the complicated history that precedes the current debate but in the ways those conflicting claims for the landscape and its use or abuse are being represented in the debate, and the politics of those representations. The State acknowledges that protection of the rock art was inadequate in the past, but contests the claim of the National Trust that $20 \%$ has already been lost due to pollution and/or removal for development. It claims that its current management role, which includes providing funding over the next two financial years for archaeological and ethnographic inventory surveys, to be undertaken by a variety of means, including the provision of expert advice, complies with its duty of care "with respect to Aboriginal heritage", reflected in the Aboriginal Heritage Act 1972. Two further management initiatives in the early stages of implementation for the Dampier Archipelago, one of which will be to establish an "environment 
and heritage management coordinating body", the other to develop a heritage management plan, ${ }^{22}$ will enhance the government's desire to support major resource development while at the same time acknowledging traditional claims to the land.

A native title body was founded in 1994 to represent the Aboriginal peoples of the Murchison, Gascoyne and now the Pilbara regions, the Yamatji Barna Baba Maaja Aboriginal Corporation. One of their Legal Officers describes their position: "In the Pilbara", he writes, "the YMBBMAC stands at the intersection of billions of dollars of new industrial and resource development with 40,000 years of culture and history". ${ }^{23}$ Together with the Pilbara Native Title Service they led the negotiations in 2000 for State acquisition of native title over specific areas of land on the Burrup, acting as a "broker between the traditional owners and the resources industry". ${ }^{24}$ These negotiations resulted in an agreement reached after a couple of years of intensive negotiation which has been called the "most famous" of the land use agreements achieved by a Land Council in Australia to date, and the most comprehensive. Yet although an agreement was successfully and speedily concluded with so-called "just terms" compensation to the Aboriginal groups, largely because those groups presented a united front, not letting their own internal politics interrupt negotiations, a lawyer working with the PNTS concedes that "implementation has proceeded at a moderate pace to date". ${ }^{25}$

Another commentator on the legal, policy and institutional context within which mineral development occurs on Aboriginal land in Australia, Ciaran O'Faircheallaigh, writes more cautiously. He describes the significant changes that have taken place in that context since the 1990s, with the enactment of the legal recognition of native title and more importantly perhaps with resource companies adopting "corporate social responsibility" policies towards Indigenous groups. But despite the changes to a situation which in the past left Aboriginal people marginalised and alienated, he asks whether these "shifts in legal frameworks and public and corporate policies" have brought about "real changes in the relationships between Aboriginal people, mining companies and the state in contemporary Australia?" ${ }^{26}$ Noel Pearson, director of the Cape York Institute for Policy and Leadership for Indigenous people wrote recently of the "Boom and dust lifestyle" that the contemporary minerals boom has brought to the Australian people. He has good evidence that Indigenous communities are missing out on the benefits of the booming economy, taking place more often than not on their land, and argues that "the starkest contrast of benefit and burden" exists in the Pilbara. ${ }^{27}$ He concludes "I am not an opponent of mining and in fact firmly believe that sustainable resource development is reconcilable with indigenous social and cultural sustainability in remote Australia and not a burden". Without the 
opportunity such a reconciliation offers to indigenous people, he writes, they "have no future in remote Australia". 28

The contrast between the romance of the Pilbara landscape and mining of that land presented in Japanese Story and the economic and political realities of the story of heavy industrial development on the Burrup Peninsula is clear, although that too has its romance. The third story of this landscape and its boom economy is that of the ancient spiritual significance of the Burrup to its traditional title holders, providing a stark contrast with the others. Each of these narratives is implicated in the other and each can tell the other something. Whether such stories can be reconciled, in Noel Pearson's terms, is not decided, nor is the question of whose representational politics will eventually dominate.

5 Marcus Clarke, Preface to Poems, (1880), p vi.

6 Henry Lawson, 'The Drover's Wife', in Best Australian Short Stories, eds Douglas Stewart

\& Beatrice Davis, Victoria: Lloyd O’Neill, 1971, p 1.

7 Roslynn D. Haynes, Seeking the Centre: The Australian Desert in Literature, Art and Film,

Cambridge: Cambridge University Press, 1998, p 28.

8 Ross Gibson, South of the West: Postcolonialism and the Narrative Construction of

Australia, Bloomington and Indianapolis, Indiana University Press, 1992, p 71.

9 For a discussion of Aboriginal Land Rights, see 'Blackfellas and Whitefellas: Aboriginal Land Rights, The Mabo Decision, and the Meaning of Land', Ronald Paul Hull, Human

Rights Quarterly, 17:2, 1995, pp 1-19.

10 Henry Handel Richardson, Australia Felix, Ringwood, Victoria: Penguin Books, 1971 (first ed. 1917), p 8.

11 Haynes, p 14.

12 Hull, p 6.

13 Gibson, South of the West, p 63.

${ }_{14}$ Felicity Collins, 'Japanese Story: A Shift of Heart', Senses of Cinema, 29, 2003, p 4.

15 Collins, p 5.

16 Graeme Turner, National Fictions: Literature, Film and the Construction of Australian Narrative, Sydney: Allen \& Unwin, 1986, p 25.

17 Japanese Story, directed by Sue Brooks, screenplay by Alison Tilson, distributed by World Cinema Ltd, released (US) 2004.

${ }_{18}$ Frances Flanagan, 'The Burrup Agreement: a case study in future act negotiation', paper presented to the National Native Title conference, Alice Springs, 3-5 June, 2003, p 2.

19 In Flanagan.

20 Western Australian Government Submission to the Australian Heritage Council, March 2006, p 4.

21 As above.

22 Submission to the Australian Heritage Council, all from p 25.

23 David Ritter, "'Don't Call Me Baby": Ten years of the Yamatji Marlpa Land and Sea

Council Native Title Representative Body', Indigenous Law Bulletin, 2004, p 1.

24 Ritter, p 4.

25 Flanagan, p 19. 
${ }_{26}$ Ciaran O'Faircheallaigh, “Aborigines, Mining Companies and the State in Contemporary Australia": A New Political Economy or "Business as Usual"?', Australian Journal of Political Science, 41:1, 2006, pp 1-22, p 2.

27 Noel Pearson, 'Boom and dust lifestyle', The Weekend Australian, 'Inquirer', February 3-4,

2007, p 29.

28 Pearson, p 29. 